\title{
Detecção dos genes de Staphylococcus aureus, enterotoxinas e de resistência à meticilina em leite
}

\author{
[Detection of genes of Staphylococcus aureus, enterotoxins and \\ methicillin resistance in milk] \\ N.L. Dias ${ }^{1}$, D.C.B. Silva ${ }^{2}$, D.C.B.S. Oliveira ${ }^{2}$, \\ A.A. Fonseca Junior ${ }^{1}$, M.L. Sales ${ }^{1}$, N. Silva ${ }^{1}$ \\ ${ }^{1}$ Escola de Veterinária - UFMG \\ Caixa Postal 567 \\ 30123-970 - Belo Horizonte, MG \\ ${ }^{2}$ Médica veterinária autônoma
}

\section{RESUMO}

Realizou-se a detecção do gene de Staphylococcus aureus, de enterotoxinas e de resistência à meticilina com extração de DNA feita diretamente de amostras de leite. Das 200 amostras estudadas, 145 (72,5\%) amplificaram o gene femA, e estas foram analisadas quanto à presença dos genes sea, seb, sec e mecA. Os genes das enterotoxinas mais prevalentes foram: sea $(60 \%)$, seb $(37,9 \%)$ e sec $(6,9 \%)$. Foram encontradas 18 amostras de leite $(11,0 \%)$ com $S$. aureus portadores do gene mecA. A detecção de $S$. aureus diretamente do leite, sem a necessidade de isolamento bacteriano e a caracterização do potencial enterotoxigênico, demonstra que a técnica de PCR é muito útil para estudos epidemiológicos das infecções estafilocócicas da glândula mamária. O alto percentual $(72,5 \%)$ de amostras de leite positivas para a presença do gene femA sugere que $S$. aureus constitui um dos principais agentes causadores de infecções intramamárias na microrregião de Sete Lagoas-MG e que seu potencial enterotoxigênico e presença do gene mecA, que identifica o $S$. aureus resistente à meticlina, representa um risco potencial à saúde pública.

Palavras-chave: Staphylococcus aureus, enterotoxinas, MRSA, PCR

\begin{abstract}
This work was performed to detect the Staphylococcus aureus gene, enterotoxins resistance to methicillin with the extraction of DNA directly from milk samples. Of the 200 samples studied 145 (72.5\%) amplified the femA gene, which were analyzed regarding the presence of sea, seb, sec and mecA genes. The most prevalent enterotoxins genes were: sea (60\%), seb (37.9\%) and sec (6.9\%). 18 milk samples (11 \%) had $\mathrm{S}$. aureus carrying the mecA gene. The detection of $\mathrm{S}$. aureus directly from the milk, with no need for bacterial isolation and the characterization of the enterotoxigenic potential demonstrate that the PCR technique is very useful for epidemiological studies of staphylococcal infections of the mammary gland. The high percentage (72.5\%) of positive milk samples for the presence of the femA gene suggests that $\mathrm{S}$. aureus constitutes of the main agents which cause intramammary infections in the micro region of Sete Lagoas-MG and that its enterotoxigenic potential and the presence of the mecA gene, which identifies the S. aureus resistant to methicillin, represent a potential risk to public health.
\end{abstract}

Keywords: Staphylococcus aureus, enterotoxins, $M R S A, P C R$

Recebido em 5 de maio de 2010

Aceito em 2 de setembro de 2011

E-mail: natanaelld@yahoo.com.br 


\section{INTRODUÇÃO}

O Staphylococcus aureus destaca-se como um dos microrganismos mais frequentemente associados às infecções intramamárias de bovinos em todos os continentes e o agente que isoladamente determina as maiores perdas na pecuária leiteira (Vasudevan et al., 2003; Costa, 2008). No Brasil, S. aureus é considerado o principal agente causal da mamite bovina, com taxas de isolamento variáveis entre $8,3 \%$ e 49,2\% (Costa, 2008).

$S$. aureus pode produzir enterotoxinas (SE) que são os principais agentes de intoxicação de origem bacteriana no homem e são caracterizadas por náusea, vômito, diarréia, dor de cabeça, cólica abdominal, cãibra muscular, queda de pressão sanguínea e prostração (Lamaita et al., 2005). As SE possuem uma estrutura compacta, que confere resistência a enzimas proteolíticas como pepsina, tripsina, renina e papaína (Bergdoll, 1989), e que, dessa forma, resiste à hidrólise pelas enzimas gástricas e jejunais, mantendo sua atividade no trato digestivo após ingestão (Luz, 2008). Entre outras propriedades, as enterotoxinas são estáveis ao aquecimento a $100^{\circ} \mathrm{C}$ durante 30 minutos, e não são inativadas totalmente pela pasteurização e por outros tratamentos térmicos usuais (Bergdoll, 1989).

Nas últimas décadas, tem-se observado a emergência de microrganismos resistentes aos antibióticos, dentre os quais se destaca $S$. aureus, resistente à meticilina (MRSA - ou Methicillinresistant Staphylococcus aureus). Essas linhagens não são comumente relatadas em animais, entretanto, nos últimos anos, há registros de aumento de casos de infecções em animais domésticos (Rich et al., 2005), sugerindo que as infecções mamárias por MRSA, em bovinos leiteiros, podem ser consideradas sério problema no campo (Lee et al., 2004).

Devido à importância das enterotoxinas estafilocócicas veiculadas em alimentos e à resistência dos $S$. aureus a antibióticos utilizados no tratamento de mamite, este trabalho teve o objetivo de detectar, em leite de tanques de refrigeração, o gene femA, que é específico de $S$. aureus, e também genes que codificam as enterotoxinas estafilocócicas (SE) A, B e C, além do destaque para detecção dos genes específicos de MRSA.

\section{MATERIAL E MÉTODOS}

Foram utilizadas 200 amostras de leite obtidas em tanque de refrigeração de propriedades rurais pertencentes à microrregião de Sete Lagoas, MG, coletadas no período de março a junho de 2009. Essas amostras foram cedidas pelo Laboratório de Análise de Leite da Escola de Veterinária da UFMG. O leite continha azidiol, substância bacteriostática que possui como princípio ativo clorafenicol e azida sódica, que permite a conservação estável da amostra por até uma semana, sem modificação dos seus componentes.

O protocolo de PCR empregado foi baseado nos trabalhos de Silva e Silva (2005) e Silva (2008). Utilizou-se a técnica da PCR para detecção do gene femA, que identifica o $S$. aureus. Esta mesma técnica foi utilizada para a detecção dos genes sea, seb, sec, que estão relacionados ao potencial de produção das enterotoxinas A, B e C respectivamente. Foi também pesquisada a presença do gene mecA, que identifica MRSA. $\mathrm{Na}$ Tab. 1 mostra-se a sequência de iniciadores referente a cada gene pesquisado.

Tabela 1. Iniciadores utilizados na PCR para identificação dos genes femA, sea, seb, sec e mecA.

\begin{tabular}{|c|c|c|c|}
\hline Iniciador & Sequência de primers 5 '-3' & Gene & $\begin{array}{l}\text { Tamanho do } \\
\text { produto }(\mathrm{pb})\end{array}$ \\
\hline FemA 1 & AAAAAAGCACATAACAAGCG & femA & 132 \\
\hline FemA 2 & GATAAAGAAGAAACCAGCAG & & \\
\hline SEA1 & GGTTATCAATGTGCGGGTGG & sea & 102 \\
\hline SEA2 & CGGCACTTTTTTCTCTTCGG & & \\
\hline SEB 1 & GTATGGTGGTGTAACTGAGC & $s e b$ & 164 \\
\hline SEB2 & CCAAATAGTGACGAGTTAAGG & & \\
\hline SEC1 & AGATGAAGTTAGTTGATGTGTATGG & $\sec$ & 451 \\
\hline SEC2 & CACACTTTTAGAATCAACCG & & \\
\hline MecA1 & AGT TCT GCA GTA CCG GAT TTG C & mecA & 533 \\
\hline MecA2 & AAA ATC GAT GGT AAA GGT TGG C & & \\
\hline
\end{tabular}


A sequência de nucleotídeos e a localização gênica foram derivadas de sequências publicadas dos genes sea (Betley e Mekalanos, 1988), seb (Johnes e Khan, 1988), sec (Bohach e Schillievert, 1987) femA (Berger-Bachi et al., 1989) e mecA, descritos por Lee (2003).

A extração de DNA foi realizada segundo protocolo proposto por Millar et al. (2000). Amplificações eficientes e reproduzíveis foram padronizadas no termociclador Px2 Thermal Cycler (Thermo Electron Corporation) com volume final de reação de $20 \mu \mathrm{L}$. Utilizaram-se $20 \%$ de tampão especial IVB 5x (Phoneutria, Brasil), 10 $\mu \mathrm{mol} / \mathrm{L}$ dos iniciadores, 200pmol/L de dNTPs, 5,0U de Taq polimerase e aproximadamente 100ng de DNA. A quantidade de DNA foi mensurada por densidade óptica em espectrofotômetro (NanoVue GE Healthcare). As condições de ciclagem para análise dos genes femA, sea e seb foram de $94{ }^{\circ} \mathrm{C}$ por cinco minutos, seguidos por 40 ciclos de 30 segundos a $94^{\circ} \mathrm{C}, 30$ segundos a $57^{\circ} \mathrm{C}$ e 30 segundos a $72^{\circ} \mathrm{C}$, e incubação final de quatro minutos a $72^{\circ} \mathrm{C}$. Para análise dos genes sec e mecA, foi utilizada a seguinte programação: $94^{\circ} \mathrm{C}$ por cinco minutos, seguidos por 30 ciclos de um minuto a $94^{\circ} \mathrm{C}$, um minuto a $57^{\circ} \mathrm{C}$, um minuto a $72^{\circ} \mathrm{C}$, e incubação final de 4 minutos a $72^{\circ} \mathrm{C}$.

As amostras padrão de $S$. aureus: ATCC 13565, ATCC 14458, ATCC 19095 possuem, respectivamente, os genes para produção de enterotoxinas (SE) A, B e C, e a amostra-padrão ATCC 33591 o gene mecA. Para os testes de especificidade analítica da PCR utilizou-se o sequenciamento dos genes sea, seb, sec, mecA e femA, usando, respectivamente, o DNA das amostras de referência ATCC 13565, ATCC 14458, ATCC 19095 e ATCC 33591 e ATCC 25923.

O DNA do fragmento amplificado foi submetido à PCR de sequenciamento utilizando-se o DYEnamic ET Dye Terminator Kit (GE Healthcare), conforme instruções do fabricante. O programa de termociclagem foi o mesmo usado para a amplificação dos fragmentos dessa região. Para o sequenciamento, usou-se o sequenciador ABI Prism 3700 DNA Sequencer (Applied Biossytems, Foster City, USA).

Para a análise das sequências e a obtenção do dendrograma, foram utilizados softwares específicos conforme metodologia utilizada por Wichert et al. (2009). Após a análise, as sequências de DNA qualificadas foram comparadas em banco de dados (GenBank, www.ncbi.nlm.nih.gov/Genbank), por meio da ferramenta BLAST (Altschull et al., 1997) para verificação da sua similaridade em relação às sequências já depositadas no Genbank.

As amostras de leite, após extração do DNA, foram inicialmente processadas com o iniciador FemA. Dessas amostras, apenas as com amplificação positiva foram submetidas à avaliação com os demais iniciadores (SEA, SEB, SEC e MecA).

As amostras-padrão de $S$. aureus ATCC 13565, ATCC 14458, ATCC 19095 e ATCC 33591 foram utilizadas também para padronização da técnica de PCR, do teste de sensibilidade e do controle positivo de $S$. aureus produtor de enterotoxina A, $S$. aureus produtor de enterotoxina $\mathrm{B}, \quad S$. aureus produtor de enterotoxina $C$ e MRSA. O DNA extraído do $S$. epidermidis (ATCC 12228) foi utilizado como controle negativo.

A sensibilidade analítica da técnica foi avaliada após a inoculação das amostras de referência de S. aureus em meio Brain Heart Infusion (BHI) e incubação à temperatura de $36^{\circ} \mathrm{C}$ por 24 horas. Após esse período, foram realizadas diluições decimais de cada amostra de referência em tubos de ensaio contendo $9 \mathrm{~mL}$ de leite estéril que sabidamente não amplificavam nenhum dos genes estudados. No primeiro tubo, foi colocado $1 \mathrm{~mL}$ da cultura crescida em meio BHI (diluição $10^{-1}$ ), e seguidamente transferidos para os demais tubos até obter a diluição final de $10^{-9}$ (Silva et $a l .$, 1997). O leite que estava nos tubos de ensaio com as diluições de $S$. aureus na base 10 foram submetidos à extração do DNA. Foi realizada a reação de PCR com os iniciadores específicos para cada amostra-padrão, com o objetivo de verificar em até qual diluição ocorreria a formação de produtos de PCR. Para obter o valor da contagem presuntiva de $S$. aureus nas diluições realizadas e avaliar a sensibilidade analítica da PCR utilizada, realizou-se contagem bacteriana em placa para cada uma dessas amostras-padrão de $S$. aureus empregando-se a técnica de profundidade em placa (pour plate) (Swanson et al., 2001). Essa técnica foi utilizada da seguinte forma: o meio BHI fundido e à 
temperatura de $47^{\circ} \mathrm{C}$ foi vertido sobre a placa de Petri contendo $1 \mathrm{~mL}$ da suspensão diluída da amostra; após $24 \mathrm{~h}$ de incubação, o número de colônias contadas foram mutiplicadas pelo fator 10 e, em seguida, pela recíproca da diluição correspondente à placa de contagem.

\section{RESULTADOS E DISCUSSÃO}

Houve amplificação do gene femA em 145 $(72,5 \%)$ amostras de leite estudadas, sugerindo ser este um dos principais agentes causadores de mamite naquela região. A utilização do gene femA, como marcador epidemiológico para detecção e identificação de $S$. aureus, a partir de amostras de leite, mostrou-se útil em estudos populacionais sobre a dinâmica das infecções intramamárias (Veras, 2004; Costa, 2008).

A especificidade analítica foi verificada pelo sequenciamento, que constatou por meio da Blast altas porcentagens de identidade e valores de $e$ e score confiáveis para os fragmentos obtidos dos genes sea, seb, sec, mecA e femA. A especificidade dessa técnica foi também estudada por Costa (2008), que constatou, pela PCR, a amplificação do gene femA em $97,7 \%$ das 360 amostras de bactérias isoladas de casos de mamite clínica e subclínica, identificadas fenotipicamente como $S$. aureus.

$\mathrm{O}$ resultado da contagem bacteriana em placas foi de $1,9010^{-9} \mathrm{UFC} / \mathrm{mL}$ para a amostra ATCC $13565 ; 1,3210^{-9} \mathrm{UFC} / \mathrm{mL}$ para a amostra ATCC 14458, $1,9810^{-9} \mathrm{UFC} / \mathrm{mL}$ para a amostra ATCC19095 e 2,07 10 ${ }^{-9} \mathrm{UFC} / \mathrm{mL}$ para a amostra ATCC 33591. Observou-se que, para os cinco genes testados (sea, seb, sec, mecA e femA), houve amplificação de produtos de PCR dentro do tamanho esperado até a diluição de $10^{-9}$ constatado pela eletroforese em gel de agarose $1,5 \%$ e corados com brometo de etídio $(1,5 \mathrm{mg} / \mathrm{mL})$, visualizados sob luz ultravioleta.

Os limites de detecção dos genes de S. aureus alcançados neste trabalho foram maiores que os obtidos por Ramesh et al. (2005) e Silva (2008), que detectaram amplificação de produtos de PCR até a diluição de $10^{-8}$ e $10^{-9}$, respectivamente . Essa diferença de sensibilidade pode ser explicada pela metodologia empregada na extração de DNA e, também, pela diferença dos iniciadores utilizados para a reação de PCR, entre os trabalhos.
Entre as amostras analisadas, $16(11,0 \%)$ delas amplificaram o gene $m e c A$, que é específico de MRSA. O primeiro trabalho a analisar a presença de MRSA em extração de DNA feita diretamente do leite, a partir da detecção do gene $m e c A$, foi o realizado por Silva (2008), que identificou uma $(3,3 \%)$ entre 30 amostras de leite de tanque de expansão, procedentes de várias regiões produtoras de leite de Minas Gerais. O maior número de amostras utilizadas neste trabalho, todas procedentes da microrregião de Sete Lagoas, cuja produção é de 186.605 mil litros de leite/ano (Instituto Brasileiro de Geografia e Estatísticas, 2009), torna este trabalho mais representativo, evidenciando a disseminação desse tipo de microrganismo entre os rebanhos produtores de leite, o que sugere serem as infecções mamárias por MRSA, em bovinos leiteiros, um sério problema no campo, como afirmaram Lee et al. (2004).

Das 145 amostras que amplificaram o gene femA, $87(60 \%)$ amplificaram o gene sea, sendo este o mais prevalente, $55(37,9 \%)$ amplificaram o gene seb e, $10(6,9 \%)$ amplificaram o gene sec. Ocorreu coamplificação dos genes, $s e a+s e b$, em 42 amostras $(28,9 \%)$, sea + sec, em nove amostras $(6,2 \%)$ e de, $s e b+s e c$, em três amostras $(2,06 \%)$. Ocorreu também a coamplificação dos três genes $s e a+s e b+s e c$ em três amostras $(2,06 \%)$. Os resultados observados neste estudo foram coerentes com os encontrados por Veras (2004), Silva (2004) e Nader Filho et al. (2007), que também utilizaram a técnica de PCR, com predominância de amostras de $S$. aureus que possuíam o gene sea, seguida de seb e posteriormente sec. A associação de sea+seb também predominou entre os achados destes autores.

Resultados divergentes foram apresentados por Cardoso et al. (2000), ao caracterizarem a produção de enterotoxinas estafilocócicas por 127 amostras de $S$. aureus, isoladas de leite proveniente de vacas com mamite em Minas Gerais, pela técnica de OSP (dupla difusão em gel), em que observaram o predomínio de amostras produtoras de enterotoxina (SE) D, seguida de B, C e A. Luz (2008) também obteve resultado divergente ao deste trabalho no que se refere à presença das enterotoxinas clássicas, pois nos 94 isolados de $S$. aureus de amostras de leite provenientes de vacas com mamite, nenhum apresentava os genes sea, seb e sec, e houve 
apenas a amplificação dos segmentos de tamanho esperado nas amostras de referência usadas como controle positivo. Os genes identificados foram os responsáveis pela produção das enterotoxinas (SE) G, H, I e J. Segundo Pinheiro de Sá et al. (2004), as SEB predominaram em estudo realizado em amostras de $S$. aureus isoladas de rebanhos com infecções subclínicas. Para esses autores, os resultados apresentados diferem em sua grande maioria, o que deve refletir a importância da genotipagem de amostras de $S$. aureus para uma melhor interpretação. As variações observadas na distribuição dos genes toxigênicos neste e em outros estudos realizados podem estar relacionadas às diferenças geográficas, devido a diferentes condições ambientais, bem como à natureza dos isolados de S. aureus.

\section{CONCLUSÕES}

$\mathrm{O}$ alto percentual de amostras de leite que tiveram o gene $f e m A$ amplificado sugere que o $S$. aureus constitui um dos principais agentes causadores de infecções intramamárias na microrregião de Sete Lagoas-MG. A técnica de PCR utilizada neste estudo apresentou alta especificidade e sensibilidade analítica para diagnóstico de $S$. aureus, enterotoxinas estafilocócicas e MRSA no leite. A técnica de PCR, que utilizou DNA de extrações realizadas diretamente do leite, para identificação de $S$. aureus e determinação do seu potencial enterotoxigênico, mostrou-se útil para estudos epidemiológicos sobre infecções intramamárias causadas por $S$. aureus.

\section{REFERÊNCIAS BIBLIOGRÁFICAS}

ALTSCHUL, S.F.; MADDEN, T.L.; SCHÄFFER, A.A. et al. Gapped BLAST and PSI-BLAST: a new generation of protein database search programs. Nucleic Acids Res., v.25, p. 3389-3402, 1997.

BERGDOLL, M.S. Staphylococcus aureus. In: FOODBORNE bacterial pathogens. New York: Marcel Dekker, 1989. p.463-523.

BERGER-BACHI, B.; BARBERIS-MAINO, L.; STRASSLE, A. et al. FemA, a hostmediated factor essential for methicillin resistance in Staphylococcus aureus: molecular cloning and characterization. Mol. Gen. Genet., v.219, p.263-269, 1989.
BETLEY, M.J.; MEKALANOS, J.J. Nucleotide sequence of type A staphylococcal enterotoxin gene. $J$. Bacteriol., v.170, p.34-41, 1988.

BOHACH, G.A.; SCHLIEVERT, P.M. Nucleotide sequence of the staphylococcal enterotoxin $\mathrm{C} 1$ gene and relatedness to other pyrogenic toxins. Mol. Gen. Genet., v.209, p.15-20, 1987

CARDOSO, H.F.T.; COSTA, G.M.; SILVA, N. Susceptibilidade a antimicrobianos de Staphylococcus aureus isolados de leite bovino no Estado de Minas Gerais. Rev. Bras. Med. Vet., v.22, p.199-206, 2000.

COSTA, G.M. Mamite bovina em rebanhos leiteiros da região sul do estado de Minas Gerais. 2008. $123 \mathrm{f}$. Tese (Doutorado em Ciência Animal) - Escola de Veterinária - Universidade Federal de Minas Gerais, Belo Horizonte, MG.

INSTITUTO BRASILEIRO DE GEOGRAFIA E ESTATÍSTICAS. Produção de origem animal por tipo de produto. Disponível em: <http://www.sidra.ibge.gov.br/bda/tabela/protabl.asp? $\mathrm{c}=74 \& \mathrm{z}=\mathrm{t} \& \mathrm{o}=24 \& \mathrm{i}=\mathrm{P}>$. Acessado em: 25 ago. 2009.

JOHNES, Jr., M.B.; KHAN, A. Staphylococcal enterotoxin $\mathrm{B}$ gene is associated with discrete genetic element. J. Bacteriol., v.170, p.4033-4039, 1988.

LAMAITA, H.C.; CERQUEIRA, M.M.O.P.; CARMO, L.S. et al. Contagem de Staphylococcus sp. e detecção de enterotoxinas estafilocócicas e toxina da síndrome do choque tóxico em amostras de leite cru refrigerado. Arq. Bras. Med. Vet. Zootec., v.57, p.702709, 2005.

LEE, J.H. Methicillin (Oxacillin)-Resistant Staphylococcus aureus strains isolated from major food animals and their potencial transmission to humans. Appl. Environ. Microbiol., v.69, p.64896494, 2003

LEE, J.H.; JEONG, J.M.; PARK, Y.H. et al. Evaluation of the Methicillin-Resistant Staphylococcus aureus (MRSA)-Screen latex agglutination test for detection of MRSA of animal origin. J. Clin. Microbiol., v.42, p.2780-2782, 2004.

LUZ, I. S.. Caracterização molecular das toxinas em Staphylococcus aureus isolados de leite e queijo de coalho em municípios da região agreste de Pernambuco. 2008. 125f. Dissertação (Mestrado em Saúde Pública) - Centro de Pesquisas Aggeu Magalhães, Fundação Oswaldo Cruz, Recife, PE.

MILLAR, B.C.; JIRU, X.; MOORE, J.E. A simple and sensitive method to extrat bacterial, yeast and fungal DNA from blood culture material. J. Microbiol. Methods, v.42, p.139-147, 2000. 
NADER FILHO, A.; FERREIRA, L.M.; AMARAL, L.A. et al. Produção de enterotoxinas e da toxina da síndrome do choque tóxico por cepas de Staphylococcus aureus isoladas na mastite bovina. Arq. Bras. Med. Vet. Zootec., v.59, p.1316-1318, 2007.

PINHEIRO de SÁ, M.E.; CUNHA, M.L.R.S.; ELIAS, A.O. et al. Importância do Staphylococcus aureus nas mastites subclínicas: pesquisa de enterotoxinas e toxina do choque tóxico, e a relação com a contagem de células somáticas. Braz. J. Vet. Res. Anim. Sci. v.41, p.320-326, 2004.

RAMESH, A.; PADMAPRIYA, B.P.; CHANDRASHEKAR, A. et al. Application of a convenient DNA extraction method and multiplex PCR for the direct detection of Staphylococcus aureus and Yersinia enterocolitica in milk samples. $\mathrm{Mol} \mathrm{Cel}$ Probes., v.16, p.307-314, 2005.

RICH, M.; DEIGHTON, L.; ROBERTS, L. Clindamycin resistence in Methicillin-resistant Staphylococcus aureus isolated from animals. Vet. Microbiol., v.111, p.237-240, 2005.

SILVA, E.R. Genotipagem e avaliação do potencial enterotoxigênico de amostras de Staphylococcus aureus isoladas de mastite caprina e bovina. 2004. 57f. Tese (Doutorado em Ciência Animal) - Escola de Veterinária, Universidade Federal de Minas Gerais, Belo Horizonte, MG.

SILVA, E.R.; SILVA, N. Coagulase gene typing of Staphylococcus aureus isolated from cows with mastitis in southeastern Brazil. Can. J. Vet. Res., v.69, p.260-264, 2005.
SILVA, M.A. Utilização de PCR Multiplex para o diagnóstico etiológico da mastite bovina. 2008. 35f. Dissertação (Mestrado em Ciência Animal) - Escola de Veterinária, Universidade Federal de Minas Gerais, Belo Horizonte, MG.

SILVA, N.; JUNQUEIRA, V.C.A.; SILVEIRA, N.F.A. Manual de métodos de análise microbiológica de alimentos. São Paulo: Varela, 1997. p.32-36, 54-57.

SWANSON, K.M.J.; PETRAN, R.L.; HANLIN, J.H. Culture methods for enumeration of microorganisms. In: DOWNES, F.P.; ITO, K. (Eds.) Compendium of methods for the microbiological examination of foods. 4.ed. Washington: American Public Health Association, 2001. p.53-62.

VASUDEVAN, P.; NAIR, M.K.M.; ANNAMALAI, T.A. et al. Phenotypic and genotypic characterization of bovine mastitis isolates of Staphylococcus aureus for biofilm formation. Vet. Microbiol., v.92, p.179185,2003

VERAS, J.F. Identificação por PCR de genes para produção de SEA, SEB, SEC e SED em linhagens de Staphylococcus sp. Isolados de surtos de toxinfecção alimentar por leite e derivados. 2004. 82f. Dissertação (Mestrado em Medicina Veterinária) - Escola de Veterinária, Universidade Federal de Minas Gerais, Belo Horizonte, MG.

WICKERT, E.; GOES, A.; LEMOS, E.G.M. et al. Relações filogenéticas e diversidade de isolados de Guignardia spp. oriundos de diferentes hospedeiros nas regiões ITS1-5,8S-ITS2. Rev. Bras. Frutic., v.31, p.360-380, 2009. 